\title{
Effect of zinc and benzene on respiration and excretion of mussel larvae (Perna perna) (Linnaeus, 1758) (Mollusca; Bivalvia)
}

\author{
Jorge, RADLVC. ${ }^{\text {** }}$,Lemos, D. ${ }^{\mathrm{b}}$ and Moreira, GS. ${ }^{\mathrm{c}}$ \\ a Centro de Recursos Hídricos e Ecologia Aplicada, EESC, University of São Paulo, \\ Rua João Gioielli, 51/44, Butantã, CEP 05540-070, São Paulo, SP, Brazil \\ ${ }^{b}$ Departamento de Oceanografia Biológica, Instituto de Oceanográfico, University of São Paulo, Brazil

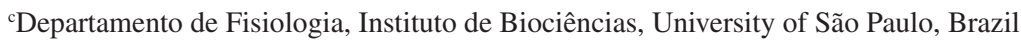 \\ *e-mail: robertaadriana@yahoo.com.br
}

Received September 8, 2004 - Accepted February 24, 2005 - Distributed February 28, 2007

(With 3 figures)

\begin{abstract}
The presence of pollutants in the ocean may affect different physiological parameters of animals. Oxygen consumption and ammonia excretion were evaluated in D-shaped larvae of mussels (Perna perna) exposed to zinc sulphate $\left(\mathrm{ZnSO}_{4}\right)$ and benzene $\left(\mathrm{C}_{6} \mathrm{H}_{6}\right)$. When compared to the control group, both pollutants presented a significant reduction in oxygen consumption. A reduction in the ammonia excretion was also observed, both for $\mathrm{ZnSO}_{4}$ and $\mathrm{C}_{6} \mathrm{H}_{6}$ and also in the oxygen consumption. The results indicate that anaerobic metabolism may occur at the beginning of $P$. perna mussels development, as observed in veliger larvae. The O:N ratio under experimental conditions showed low values indicating that catabolism in veliger larvae was predominantly proteic.
\end{abstract}

Keywords: larvae, Perna perna, bioenergetic, zinc, benzene.

\section{Bioenergética de larvas de mexilhão (Perna perna) (Linnaeus, 1758)}

\begin{abstract}
Resumo
A presença de poluentes no oceano pode afetar diferentes parâmetros fisiológicos. O consumo de oxigênio e a excreção de amônia foram avaliados nas larvas D de mexilhão (Perna perna) expostas ao sulfato de zinco $\left(\mathrm{ZnSO}_{4}\right)$ e ao benzeno $\left(\mathrm{C}_{6} \mathrm{H}_{6}\right)$. Quando comparados ao grupo controle, ambos os poluentes apresentaram uma significativa redução no consumo de oxigênio. A redução na excreção de amônia também foi observada para o $\mathrm{ZnSO}_{4}$ e para o $\mathrm{C}_{6} \mathrm{H}_{6}$, assim como para o consumo de oxigênio. Os resultados indicam que o metabolismo anaeróbico pode ocorrer no início do desenvolvimento do mexilhão P. perna, como foi observado na larva véliger. A razão O:N apresentou baixos valores, indicando que o catabolismo nas larvas véliger foi predominantemente protéico.
\end{abstract}

Palavras-chave: larva, Perna perna, bioenergética, zinco, benzeno.

\section{Introduction}

Introducing pollutants to the marine environment is a menace to the biota and may affect marine habitats by physical, chemical and biological interactions on different temporal and spatial scales (GESAMP, 1995). Among the pollutants that can contaminate, marine environment metals and hydrocarbon are common. The main external source of heavy metals is related to industrial dumping or waste dumped straight into the sea (Clark, 1986). Zinc sulphate is a non-biodegradable (chemically or biologically) type of metal, that may be converted to different compounds, sometimes with much increased toxicity over its original component and is easily incorporated into the ecosystem (Hood et al., 1971). Hydrocarbon sources could include leakages from ships, terminals or oil platforms and also incomplete combustion processes of fossil fuels and recent plankton biosynthesis (Clark and Brown, 1977; Connell and Miller, 1984; GESAMP, 1993).

The presence of these pollutants may induce physiological changes in animals, such as energetic demand. Respiration represents an important physiological index, because it reflects metabolism and has a vital meaning for cell energetic supplies (Verriopoulos et al., 1986) whilst excretion is essential in quantifying an organism's energetic balance (Phan et al., 1993).

The aim of the present study is to determine oxygen consumption, ammonia- $\mathrm{N}$ excretion and $\mathrm{O}: \mathrm{N}$ ratio of mussels D-shaped larvae (P. perna) when exposed to 
zinc sulphate and benzene pollutants under laboratory conditions.

\section{Material and Methods}

\subsection{Experimental animals}

Mussels were collected on Taubate's coastal water $\left(23^{\circ} 54.34^{\prime} \mathrm{S}\right.$ and $\left.45^{\circ} 27.56^{\prime} \mathrm{W}\right)$ of the southern point of São Sebastião, São Paulo, Brazil. Fouling was removed, the byssus cut off and the animals washed in freshwater. Mussels were induced to release gametes by various stimuli: the removal of fouling, exposure to the air, temperature alternation, seawater filtered and sterilized by UV rays and by the presence of spontaneously liberate gametes. These mussel gametes were separated by sex and the ovocites were washed before spermatozoids. The washed ovocites complied to a net sequence going through different measures of mesh (100, 80, $70,60,50,30$ e $22 \mu \mathrm{m}$ ) and were re-suspended in a $1000 \mathrm{~mL}$ beaker, with UV sterilized and filtered seawater. The spermatozoids were recollected in a $50 \mathrm{~mL}$ beaker, in an ice bath, when only 100 and $80 \mu \mathrm{m}$ mesh were used, and then were filtered and sterilized in seawater. The ovocite number was determined by three counting, from an aliquote taken from the ovocite suspension, under an optical microscope in a SedgewickRafter chamber and was fertilized. Ovocites were kept at a constant temperature chamber $\left(24 \pm 0.5{ }^{\circ} \mathrm{C}\right)$ for one hour. After this period, they were transferred to a $7 \mathrm{~L}$ container, where a 30 embryos $/ \mathrm{mL}$ was not exceeded (ASTM, 1992). In this container, embryos stayed until they reached the D-shaped larvae stage and the container was kept at a constant temperature $\left(24 \pm 0.5^{\circ} \mathrm{C}\right)$ with weak aeration, sterilized and having filtered seawater as well as a photoperiod 12 hours light:12 hours dark. After 27 hours, the D-shaped larvae were washed in 100; 80 and $50 \mu \mathrm{m}$ nets and recollected in a $250 \mathrm{~mL}$ beaker, according to the number of larvae in this fraction and 4500 larvae were used in each respirometer.

The pollutants used were zinc sulphate $\left(\mathrm{ZnSO}_{4}\right)$ in sublethal nominal concentration of $0.47 \mathrm{mg} . \mathrm{L}^{-1}$ and benzene $\left(\mathrm{C}_{6} \mathrm{H}_{6}\right)$ in sublethal nominal concentration of $5.69 \mu \mathrm{L} . \mathrm{L}^{-1}$.Controls with no pollutant were used for comparison $(\mathrm{n}=5)$. The larvae were dried at $80{ }^{\circ} \mathrm{C}$ $\left( \pm 1.0^{\circ} \mathrm{C}\right)$ for 48 hours, and weighed on an analytical balance (Mettler Toledo) with $0.1 \mathrm{mg}$ precision.

\subsection{Oxygen consumption, ammonia- $N$ excretion and $O: N$ ratio}

The concentration of oxygen was measured by the Winkler's micro-method which is meant for small samples (Fox and Wingfiled, 1938) and modified by Lemos and Phan (2001) for larval stages of aquatic animals. The acclimation time, as well as incubation time was 5 hours. The experimental total time was determined so that the final oxygen concentration would be approximately $75 \%$ of the initial concentration, thus avoiding the hypoxic effects on the metabolic processes. Initial and final meas- ures were taken in each group, in the breathing period, for dosage solved oxygen and ammonia-N.

The difference between initial and final concentrations represented oxygen consumption and ammonia-N excretion, corresponding to this experimental condition. Closed system respirometers were used and they contained water which was not changed or re-circulated. An acclimatation period preceded the experiment, where larvae were kept in respirometers covered by a $50 \mu \mathrm{m}$ net, and maintained in a container with filtered and sterilized seawater, having weak aeration under a constant temperature $\left(24 \pm 0.5^{\circ} \mathrm{C}\right)$ of 5 hours. Then, the respirometers were tightly closed and remained for another 5 hours period in a constant temperature chamber, when part of the respirometer volume was transferred to a glass syringe where proper reagents were added to determine oxygen consumption.

To determine ammonia- $\mathrm{N}$ excretion, the used technique was based on the colorimetric method described by Koroleff (1983) and modified by Lemos and Phan (2001) for larval stages of aquatic animals. After the oxygen dosing in a sample, another aliquot was taken $(10 \mathrm{~mL})$ for dose ammonia-N. Following a specific reagent addition, the sample was read in a spectrophotometer with $630 \mathrm{~nm}$ absorbance.

The O:N ratio was calculated by the oxygen and nitrogen atomic equivalent obtained from oxygen consumption and ammonia-N excretion values of the experiments, therefore indicating the relation between oxygen consumption and excretion nitrogen (Mayzaud and Conover, 1988).

\subsection{Statistical analysis}

The non-parametric Kolmogorov-Smirnov test (K-S) (Zar, 1984) was applied to check data normality. The non paired test $t$ was able to find differences considered significant $(\mathrm{p}<0.05)$ and was used to analyse all substances. Software used to do the analysis was o GraphPad Prism® (v. 2.00).

\section{Results}

The statistic analysis showed data normality for both oxygen consumption and ammonia excretion. Animal mortality did not occur since the concentrations used were sublethal, as previously determined.

Each D-shaped larvae, with 27 hours, presented 98.45 $( \pm 8.66) \mathrm{ng}$ of dry weight and $82.05( \pm 6.67) \mu \mathrm{m}$ in length.

Oxygen consumption in the presence of $\mathrm{ZnSO}_{4}$ presented a reduction in relation to the control group [Control: $1.81124( \pm 0.25283) \quad \mathrm{nlO}_{2} \cdot \mathrm{h}^{-1}$ vs. $\mathrm{ZnSO}_{4}$ : $\left.0.71297( \pm 0.33546) \mathrm{nlO}_{2} \cdot \mathrm{h}^{-1} ; \mathrm{p}<0.05\right]$ and it was statistically significant. For $\mathrm{C}_{6} \mathrm{H}_{6}$ a reduction in oxygen consumption was also observed [Control: 1.09321 $( \pm 0.32986) \quad \mathrm{nlO}_{2} \cdot \mathrm{h}^{-1} \quad$ vs. $\mathrm{C}_{6} \mathrm{H}_{6}: 0.49511 \quad( \pm 0.35660)$ $\left.\mathrm{nlO}_{2} \cdot \mathrm{h}^{-1} ; \mathrm{p}<0.05\right]$ and so was statistically significant (Figure 1). 
Ammonia excretion was also significantly reduced by both pollutants when compared to the control group [Control: $0.02349( \pm 0.00344)$ ngat. $^{-1}$ vs. $\mathrm{ZnSO}_{4}: 0.01482( \pm 0.00534)$ ngat.h $^{-1} ; \mathrm{p}<0.05$ and Control: $0.02983( \pm 0.00827)$ ngat.h $^{-1}$ vs. $\mathrm{C}_{6} \mathrm{H}_{6}: 0.01334$ $( \pm 0.00332)$ ngat. $\left.^{-1} ; \mathrm{p}<0.05\right]$ (Figure 2).

The mean values for the O:N ratio obtained for controls of zinc sulphate were 4.0838 and were 3.8813 with pollutant. Benzene obtained values in controls of 2.5289 and 2.8736 with pollutant (Figure 3).

\section{Discussion}

Xenobiotics affect the organisms' respiration processes, inducing the animals to use other energy sources that may be employed in detoxicating reactions and metabolism patterns (Vargas et al., 1991). For mussels, zinc is an essential element and necessary for a variety of biological molecules, including enzymes and structural protein (Nolan and Dahlgaard, 1991). However, in concentrations higher than necessary, it can be deleterious for some of these functions. For instance, in high metal concentrations bivalves keep their shells closed for a long period, reducing byssus production and heart beat (Kraak et al., 1997). The closed shell can be observed

Oxygen mean consumption per individual $\left(\mathrm{nl} \mathrm{O}_{2} \cdot \mathrm{h}^{-1}\right)$

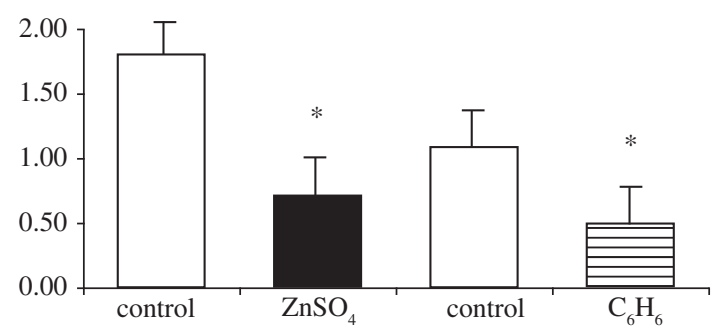

Figure 1. Oxygen mean consumption per individual $\left(\mathrm{nlO}_{2} \cdot \mathrm{h}^{-1}\right)$ in both experimental conditions for zinc sulphate and benzene pollutants. Values are mean \pm SEM, * statistic difference $(\mathrm{p}<0.05)$.

Ammonia-N excretion per individual (ng at. $\mathrm{h}^{-1}$ )

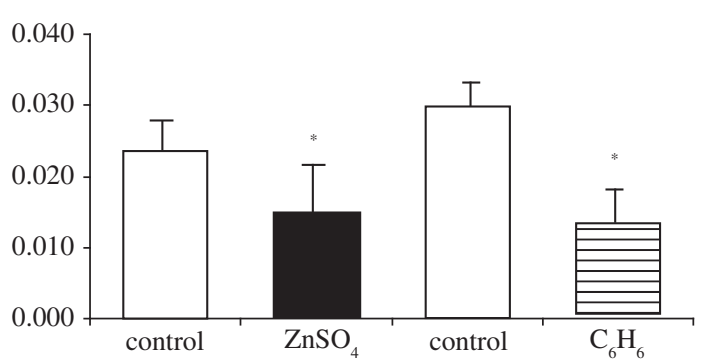

Figure 2. Ammonia-N excretion per individual $\left(\right.$ ngat.h $\left.^{-1}\right)$ in both experimental conditions for zinc sulphate and benzene pollutants. Values are mean \pm SEM, * statistical difference $(\mathrm{p}<0.05)$. in the presence of other pollutants and can induce some physiological responses. For sublethal hydrocarbon concentrations, they may cause physiological disturbance and also, development alterations, resulting in the premature death of individuals (Clark, 1986).

There is a direct correlation between the shell closing and respiration rates. When important respiration changes occur, there is a sublethal shift in the capacity of animals to fulfill their physiological processes or to adapt, and, as a result, changes in survival time, growth and reproductive potential may occur, and the respiratory response is highly affected by the concentration of pollutants (Verriopoulos et al., 1986). Some of these changes can be observed for ammonia excretion or oxygen consumption in adults of amphipod Gammarus salinus and mussel Mytilus edulis (Carr and Linden, 1984; Tedengren and Kautsky, 1987), shrimp Marsupenaeus japonicus (Chen and Chen, 1997), mysid Neomysis integer (Laughlin and Lindén, 1983), and crabs Ucides cordatus (Toledo, 1999) and Uca marionis (Yeragy and Koli, 2000)

When exposed to different pollutants, alterations in the physiology of animals may occur such as anaerobic metabolism. In mussels, exposed to long desiccation periods, anaerobic metabolism is used, e.g., in low tide in adults or extreme salinity variations. For larvae, this response may happen for other reasons. The fact that these substances can alter the physiological parameters making the environment inhospitable and inadequate, the mussel larvae are induced to close their valve, preserving homeostasis. In such a situation, the altered metabolism enables animals to use an anaerobic metabolism which is optional for aerobic or a blend of both. This behavior has been observed for some substances, such as high concentrations of ammonia, for adults and juvenile clams Mercenaria mercenaria and adult oysters Crassostrea virginica (Epifanio and Srna, 1975); heavy metals for Crassostrea virginica larvae (Calabrese et al., 1973); and organic compounds (benzene, ethyleneglycol, formaldehyde, methanol, phenol, oil and oil dispersant) for adult Mytilus edulis (Borseth et al., 1995).

Anaerobic metabolism has been thoroughly studied in adult mussels (Thompson and Bayne, 1972; Bayne,

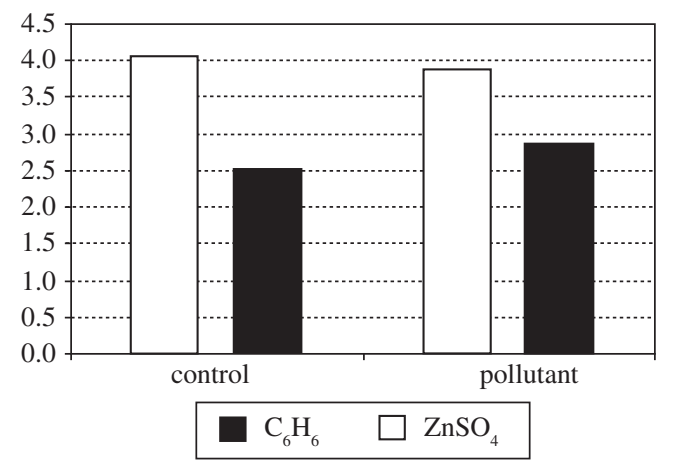

Figure 3. O:N ratio in both experimental conditions for zinc sulphate and benzene. Values are mean. 
1973; Labarta et al., 1997; Sadok et al., 1999; Babarro et al., 2000). However, the present results suggest that this response has been observed since the beginning of the development of mussels in the D-shaped larvae stage.

An additional factor to consider is the affinity that certain pollutants have towards certain chemical and structure compounds of the organism. For instance, hydrocarbons are lipophilic and zinc has a great affinity with calcium. During the development and planctonic mussel's life, this could affect the breathing metabolism and $\mathrm{O}: \mathrm{N}$ ratio consequently; but this is yet to be a confirmed hypothesis.

The O:N ratio values found in mussel's larvae exposed to different xenobiotics in the present assays were lower than 16, which indicate protein metabolism preponderancy. This index could be directly related to a stress condition, as suggested by Widdows (1978), Carr and Linden (1984), Widdows, (1985) and Vargas et al. (1991), when O:N ratio was found under 7. However, additional experiments are needed to confirm such a hypothesis, such as the obtained values in the absence of pollutants.

For the D-shaped larvae of P. perna, it was shown that the oxygen consumption for both pollutants, when compared to the control group, showed a significant decrease. A decrease in ammonia- $\mathrm{N}$ excretion was also observed in zinc sulphate and benzene and the oxygen consumption was significantly low. These results show that anaerobic metabolism can be present in the development of the P. perna mussel, as observed in the D-shaped larvae. The O:N ratio showed low values, thus indicating that the D-shaped larvae catabolism was predominantly protein in the present studied conditions.

Acknowledgments - This work and R. JORGE was supported by FAPESP (Fundação de Amparo à Pesquisa no Estado de São Paulo). We are also grateful for CEBIMAR/USP (Centro de Biologia Marinha/ Universidade de São Paulo) for the logistic support and use of facilities.

\section{References}

ASTM - AMERICAN SOCIETY FOR TESTING AND MATERIALS., 1992. ASTM E 724/89 - Standard guide for conducting static acute toxicity tests starting with embryos of four species of saltwater bivalve molluscs. In: ASTM AMERICAN SOCIETY FOR TESTING AND MATERIALS. Annual book of ASTM standards. Philadelphia, vol 11, no. 4, p. 377-394.

BABARRO, JMF., FERNÁNDEZ-REIRIZ, MJ. and LABARTA, U., 2000. Metabolism of the mussel Mytilus galloprovincialis from two origins in the Ría de Arousa (north-west Spain). $J$. Mar. Biol. Ass. U.K., vol. 80, p. 865-872.

BAYNE, B., 1973. Aspects of the metabolism of Mytilus edulis during starvation. Netherlands Journal of Sea Research, vol. 7, p. 399-410.

BORSETH, JF., AUNAAS, T., DENSTAD, JP., NORDTUG, T., OLSEN, AJ., SCHMID, R., SKJAERVO, G. and ZACHARIASSEN, KE., 1995. Transmembrane sodium energy gradientandcalciumcontentintheadductormuscleof Mytilusedulis L.inrelationtothetoxicityoilandorganicchemicals.Aquat.Toxicol., vol 31, p. 263-276.

CALABRESE, A., COLLIER, RS., NELSON, DA. and MacINNES, JR., 1973. The toxicity of heavy metals to embryos of the american oyster Crassostrea virginica. Mar. Biol., vol. 18 , p. 62-166.

CARR, RS. and LINDEN, O., 1984. Bioenergetic responses of Gammarus salinus and Mytilus edulis to oil and oil dispersants in a model ecosystem. Mar. Ecol. Prog. Ser., vol. 19, p. 285-291.

CHEN, JC. and CHEN, KW., 1997. Oxygen uptake and ammonia$\mathrm{N}$ excretion of juvenile Penaeus japonicus during depuration following one-day exposure to different concentrations of saponin at different salinity levels. Aquaculture, vol. 156, p. $77-83$.

CLARK, RB., 1986. Marine Pollution. UK. Claredon Press. Cap. 01, p. 01-10: What is pollution? Cap. 4, p. 48-66: Consequence of oil pollution. Cap. 5, p. 67-81: Conservative pollutants. Cap. 6, p. 82-104: Metals.

CLARK, RC. and BROWN, DW., 1977. Petroleum proprieties and analyze of paraffin hidrocarbons and for interpretation of data bases oil spill effects in aquatic organisms. In: Joint Conference on Prevention and Control of Oil Spills. Washington, D.C.. American Petroleum Institute, p. 161-172. Resume in ASFA, 1997.

CONNELL, DW. and MILLER, GJ., 1984. Chemisty and Ecotoxicology Pollution. USA, A Wiley-Interscience Publication. Cap 3; p. 43-68: Environmental Toxicology, cap 8, p. 228-249: Petroleum and Related Hydrocarbons.

EPIFANIO, CE. and SRNA, RF., 1975. Toxicity of Ammonia, Nitrite Ion, Nitrate Ion, and Orthophosphate to Mercenaria mercenaria and Crassostrea virginica. Mar. Biol., vol. 33, p. 241-246.

FOX, HM. and WINGFIELD, CA., 1938. A portable apparatus for the determination of oxygen dissolved in a small volume of water. J. Exp. Biol., vol. 15, p. 437-445.

GESAMP (IMO/FAO/UNESCO/WMO/WHO/IAEA/UN/ UNEP), 1993, Joint Group of Experts on the Scientific Aspects of Marine Pollution) 1993: Impact of Oil and Related Chemicals and Wastes on the Marine Environment. Rep. Stud. GESAMP, vol. $50,180 \mathrm{p}$.

-, 1995, Joint Group of Experts on the Scientific Aspects of Marine Pollution) 1995: Biological Indicators and their Use in the Measurement of the Condition of the Marine Environment. Rep. Stud. GESAMP, vol. 55, 56 pp.

HOOD, DW., FORSTER, WO., LINNENBOM, V., WALDICHUK, M., PARKER, PL., REID, JL., TUREKIAN, K. and PERKINS, R., 1971, The ultimate fate of substance that relate to the quality of the marine environment. Washington, D.C., National Academy of Sciences. 1971, Cap VI, p. 83-107: Marine Environmental Quality - Suggested Research Programs for Understanding Man's Effect on the Oceans.

KOROLEFF, F., 1983. Determination of ammonia. In: GRASSHOFF, K., EHRHARDT, A. and KREMLING, K. (eds.). Methods of seawater analysis, 2nd ed, p. 150-157, Verlag Chemie, Weinheim, Germany

KRAAK, MHS., AINSCOUGH, C., FERNÁNDEZ, A., VLAARDINGEN, PLAV., VOOGT, P. and ADMIRAAL, WA., 
1997. Short-term and chronic exposure of the zebra mussel (Dreissenia polymorpha) to acridine: effects and metabolism. Aquat. Toxicol., vol. 37, p. 09-20.

LABARTA, U., FERNÁNDEZ-REIRÍZ, MJ. and BABARRO, JMF., 1997. Differences in physiological energetics between intertidal and raft cultivated mussels Mytilus galloprovincialis. Mar Ecol Prog Ser., vol. 152, p. 167-173.

LAUGHLIN, R. and LINDÉN, O., 1983. Oil pollution and baltic mysids: acute and chronic effects of the water soluble fractions of light fuel oil on the mysid shrimp Neomysis integer. Mar Ecol Prog Ser., vol. 12, p. 29 - 41.

LEMOS, D. and PHAN, VN., 2001, Ontogenetic variation in metabolic rate biochemical composition and energy content during the early life stages of Farfantepenaeus paulensis (Crustacea: Decapoda: Penaeidae). Mar. Biol., vol. 138, p. 985-997.

MAYZAUD, P. and CONOVER, RJ., 1988. O:N atomic ratio as a tool to describe zooplankton metabolism. Mar. Ecol. Progr. Ser., vol. 45, p. 289-302.

NOLAN, C. and DAHLGAARD, H., 1991. Accumulation of metal radiotracers by Mytilus edulis. Mar Ecol Prog Ser, vol. 70, p. 165-174.

PHAN, V.N., GOMES, V., MORAIS, DM. and PASSOS, MJACR., 1993. Estudo bioenergético de animais marinhos costeiros. I. Paralonchurus brasiliensis (Perciformes, Sciaenidae). Publ. Esp. Inst. Oceanogr., S Paulo, vol. 10, p. 199-215.

SADOK, S., UGLOW, RF. and HASWELL, SJ., 1999. Some aspects of nitrogen metabolism in Mytilus edulis: effects of aerial exposure. Mar. Biol., vol. 135, p. 297-305.
TEDENGREN, M. and KAUTSKY, N., 1987. Comparative stress response to diesel oil and salinity changes of the blue mussel, Mytilus edulis from the baltic and north seas. Ophelia., vol. 1 , no. 28 , p. 01-09.

TOLEDO, ACC., 1999. Efeito do benzeno e da mudança de salinidade no consumo de oxigênio e amônia excretada no caranguejo de mangue Ucides cordatus. (Dissertação) Mestrado, Instituto de Biociências, Universidade de São Paulo. São Paulo - SP, $127 f$.

THOMPSON, RJ. and BAYNE, BL., 1972. Active metabolism associated with feeding in the mussel Mytilus edulis L. J. Exp. Mar. Biol. Ecol., vol. 9, p. 111-124.

VARGAS, M., CORREA, M. and CHUNG, KS., 1991. Indicadores fisiologicos en la evaluacion de la toxicidad de hidrocarburos aromaticos. Bol. Inst. Oceanog. Venez., Univ. Oriente, vol. 30, no 1-2, p. 57-64.

VERRIOPOULOS, G., MORAITOU-APOSTOLOPOULOU, M. and XATZISPIROU, A., 1986. Evaluation of metabolic responses of Artemia salina to oil and oil dispersant as a potential indicator of toxicant stress. Bull. Environ. Contam. Toxicol., vol. 36 , p. 444-451.

WIDDOWS, J., 1978. Physiological indices of stress in Mytilus edulis. J. Mar. Biol. Ass. U.K., vol. 58, p. 125-142.

WIDDOWS, J., 1985. Physiological response to pollution. Mar. Poll. Bull., vol. 16, no. 4, p. 129-134.

YERAGI, SG. and KOLI, VA. 2000. Effect of malathion on respiration of marine edible crab Uca marionis (DES). J. Mar. Bio. Ass. India., vol. 1-2, no. 44, p. 129-133.

ZAR, JH., 1984. Biostatistical Analysis. 2nd ed. New Jersey, Prentice Hall, Englewood Cliffs. 